\title{
An Empirical Study about Green Purchase Intentions
}

\author{
Muhammad Rizwan (Corresponding author) \\ Lecturer, Department of Management Sciences, \\ The Islamia University of Bahawalpur, Pakistan \\ E-mail: rizwan.arshad@iub.edu.pk
}

\section{Usman Mahmood}

Department of Management Sciences, The Islamia University of Bahawalpur, Pakistan

Hammad Siddiqui

Department of Management Sciences, The Islamia University of Bahawalpur, Pakistan

Arham Tahir

Department of Management Sciences, The Islamia University of Bahawalpur, Pakistan

Doi:10.5296/ jsr.v5i1.6567 URL: http://dx.doi.org/10.5296/ jsr.v5i1.6567

\begin{abstract}
Aim: The aim of this paper is to find if marketing and branding methods can help set up green brands and initiate green intention of utilization into modern lifestyles in the latest context where eco products are more and more available. The definite aim of this study is to analyze the impact of Green perceived risk, Green perceived trust, value, brand image, Green advertisement and awareness on green purchase intention of customer.

Design/methodology/approach: This paper explains the theory of green marketing to see how customers are convinced to purchase greener products. It also shows the empirical consequences of a consumer survey on green marketing strategies by the questionnaire method. The survey questionnaires were conducted to 150 respondents visiting different supermarkets. The questionnaires were processed and analyzed with the statistical software SPSS, using different techniques like descriptive, correlation and factor analysis.
\end{abstract}

Findings: The findings give some exciting clues regarding customers' perceptions on 
environmental concerns and green products. More findings propose that most consumers have spoken a great interest in the protection of the environment and they are strongly concerned about the environment and its disgrace. So, business executives should arrange workshops and seminars so as to teach customers on environmental protection and environmental-friendly products. Results also point to an overall positive correlation between effective green marketing strategies and customers' purchasing patterns for green products. Therefore, there is a strong urge for companies to promote green branding, eco-labeling and green packaging strategies in order to motivate a greener pattern of consumption among consumers.

Practical implications: The paper suggests a stepping approach to consumer purchasing intention for greener products could be exploited more within consumer groups that have strong environmental concerns and beliefs. The results also offer precious knowledge on the usefulness of green marketing strategies which can help both private and public enterprises in developing and designing attractive green products that will be privileged by customers.

Keywords: Consumer behavior, marketing strategy, Green customers, Green marketing strategies, Green consumer purchasing patterns

\section{Introduction}

For last three Decades Green marketing has been a vital academic research topic. Green consumers have become an energetic force behind how companies do business, and these environmental friendly customers are creating a new economy around the globe. Indeed, the "green consumer" idea was the epicenter of the environmental marketing strategies as well as a key idea, on which important marketing academicians and professionals focused at the end of 1980s and in the early 1990s. These studies recommend that environmental attitude, affect, adolescent consumers' green purchasing intention knowledge and memory could be significant determinants of eco-friendly behavior. This change contributes uprising to the start of the green to avoid more damage to the environment.

Rising knowledge on the various environmental problems has led a change in the way consumers go about their life. There has been a change in consumer attitudes towards a green lifestyle. People are insistently trying to reduce their impact on the environment. However, this is not wide and is still rising. Organizations and business however have seen this change in consumer attitudes and are trying to get a rim in the competitive market by exploiting the potential in the green market industry. The current study introduces the idea of green marketing and looks into the various ways in which the different consumer attributes are related to the concept of green marketing. A theoretical framework is presented and the information is analyzed on the foundation of the framework. Although green marketing is generally discussed and important issue in today world but in spite of these efforts by the marketers, green purchase intention is still under developing. Intention is a representative's particular purpose in shipping out an action or chains of actions that is expected. 


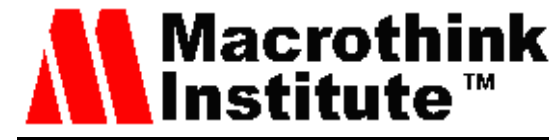

The green intention supports a person, modify their views, actions and practices from the source where the key intention drives their actions. Over the earlier eras, concern about the atmosphere has become not only a main public issue but also a critical matter in academic study. Due to the increase in environmental awareness since 1970's a lot of positive change within users' behavior can be seen towards environmental related products. This change helps to start the green revolution to save the environment from more damages. For general public, qualities, attributes and characteristics of green goods are introduced with the help of green marketing and green awareness, so, green marketing and awareness; guide them into buying environmentally friendly products very easily. This plays an important part to shift user actual buying intention to buy environmental friendly goods. Public takes interest and noticed the environmental pollution, producing by industries and manufacturer of diverse type of products. People take environmental protection as their social obligation, because environmental concern has a main issue as a result of global warming.

The purpose of this paper is to investigate if marketing and branding techniques can help set up green brands and introduce greener patterns of utilization into contemporary lifestyles in the current context where environmentally friendly products are increasingly available. And the specific the purpose of this study is to analyze the impact of Green perceived risk, Green perceived trust, value, brand image, Green advertisement and awareness on green purchase intention of customer.

Green perceived Risk is the hope of negative environmental consequences associated with purchase behavior. Green trust is defined in this study as the consumer's will to depend on a product or a service of a brand as a result of his faith in its environmental reliability.

Green Perceived value: a consumer's overall assessment of the net benefit of a product or service between what is received and what is given based on the consumer's environmental needs,

Sustainable expectations, and green needs". Green brand image is defined in this study as a set of perceptions and relations in the mind of the consumer that are connected to its environmental commitments and concerns. Green awareness is defined as the likelihood to recognize and recall the environmental features of the brand.

\section{Literature Review}

\section{Green Purchase Intention}

Green purchase intention (GPIN) is simply defined as an intention to buy a service or product which is less or not harmful for the society and environment. It can also be defined as an internal wish, desire and willingness of the people to buy a less harmful and environmental friendly product. With the developing of technology, it has some bad and negative effects on our environment like water pollution, air pollution and damage of ozone layer etc. to avoid these harmful effects, people are now more serious and aware about this issue and they are adopting a new trend. They have tendency to use such products, which have less harmful and 
less dangerous effects for environment. The society and public are taking more seriously noticed about environmental issues creating the more pollution in our environment, arisen from industrial sector's manufacturing activities (Chen, 2011; Rizwan et al., 2013). People are much conscious about the environmental problems, many customers have environmental beliefs and they are willing to purchase green products that have a less harmful impact on the environment (Peattie, 1995).

Many customers are willing to pay for less air pollution in the USA. They have a willingness to pay some more amounts for reduced emissions through renewable fuels (Porter and Van der Linde, 1995). The marketers and manufacturers needed to reorganize their manufacturing and business models to accomplish the consumer's environmental beliefs (Chen, 2010). With the review of previous researches it can be easily determined that there is a developing trend in the people to use such products that are less harmful for the environment. Even they are willing to pay more for such products, which have less effect on the environment. This willingness of the people to purchase environment friendly products called green purchase intention. Companies should practice such marketing activities that can influence consumer's attitude and create their intention to buy green products by changing the customer's evaluation. It can be done by targeting normative beliefs and by adding new beliefs. People's intention to purchase green products is based on different variables that are examined and proved to have an effect on green purchase intention. Some variables that we have founded to have much influence on green purchase intention, are discussed as under.

\section{Green Perceived Risk}

Perceived risk means the danger in the mind of one party that the other party will not act according to the contract. In other word we can say that perceived risk is the think of the buyer that the product will not according to their demand and it will not be able to fulfill their needs. Perceived risk can force customers to keep away from purchasing a product and to be saved from being deceived. Perceived risk is defined as an arrangement of vagueness and negative result, the more evaluation of perceived risk results a change in customer purchase decision (Peter and Ryan, 1976). Perceived risk theory explained that people want to lessen their perceived risk as an alternative of maximizing their utility (Mitchell, 1999). Therefore, we can easily conclude that a customer will be risk avoider while buying any new product. Perceived risk is a major obstacle in trusting any new product. Risk may be based on two things; firstly, it may be due to any bad practice of being deceived in past. Secondly, it may be due to the negative word-of-mouth. These two factors create the perceived risk and create mistrust on any product. When we talk about the green perceived risk, it refers to customer's perception that the product will be low-grade in excellence or will not be environmental friendly etc. In the early time of green marketing, many companies had adopted this practice to just claim a non-green product as a green product to get and to improve up the sales. So now, the customers are eager to reduce this practice. eventually, the consumers are not ready to purchase a product because they do not have trust on the seller due to the communication space between sellers and buyers (Gregg and Walczak, 2008; Rizwan et al., 2013). 
In a few possible words, we can say that there is a negative relationship between perceived risk and customer's green trust. If the risk were far above the ground, it would lessen the trust and would create the low GPIN. If the perceived risk is reduced, it would consequences the increase of a product's purchase possibility and it would raise the customer purchase intentions. Therefore, it proved that GPR is negatively associated with GPT (Chang and Chen, 2008; Mitchell, 1999; Wood and Scheer, 1996). If a customer has a high GPR there is a low possibility that the customer will buy the product (Mitchell, 1999). Perceived risk is one party's hope of a loss, so it would change the customer's purchasing behavior significantly (Chaudhuri, 1997). Risk perceptions have a strong positive connection with negative consumption feelings. These negative emotions have a significant and direct effect on customer's trust (Chaudhuri, 1997). Based on above-mentioned researches we can make hypothesis:

\section{H1: There is a negative relationship between green perceived risk and green purchase intention.}

\section{Green Perceived Trust}

Trust means expectation held by one party that the word, promise, or statement of another party could be relied on (Rotter, 1971; Schurr and Ozanne, 1985). There are three main causes of trust, believes on honesty, goodwill and aptitude. Trust is level of the self-assurance that another party would perform as expected (Hart and Saunders, 1997). GPT is an necessary determinant of long-term consumer activities . Hence, consumer GPT affects consumer GPIN. Past literature recommends that GPT is a determinant of GPIN . If buyers have had a good familiarity with the seller, they would have a higher level of GPIN. Thus, GPT is inventor of GPIN (van der Heijden et al. 2003). earlier study shows that customer GPT would positively impudence customer GPIN (Schlosser et al. 2006).

Recently, customers are unwilling to trust on few companies due to overemphasizing the environmental performance of their product (Kalafatis and Pollard, 1999). Chen (2010) argues that GPT would affect consumers' purchase behaviors in the environmental era. GPIN is characterizes as "the probability that a consumer would buy a particular product resulting from his or her environmental needs" ( $\mathrm{Lu}$ et al. 2010). Chen (2010) indicates that customer GPT is positively affects customer GPIN. In this situation of environmental management, this study hypothesizes that GPT of customers is positively affects their GPIN and proposes the following hypothesis:

H2: There is a positive relationship between green perceived trust and green purchase intention.

H3: There is a negative relationship between green perceived trust and green perceived risk. 


\section{Green Perceived Value}

Green perceived value (GPV) means the total benefits, features and performance of a Green product in the mind of customer. According to Spreng and Patterson (1997) and Drew and Bolton (1991) GPV is a customer evaluation about his overall benefit from Green product. Simply we can say that it is the thought of the customer that what he can gain from a green product by purchasing it. When we talk about green product and it's GPV, it refers to the valuation of the benefits and performance of green products in the mind of the customer past to use it. A product's greenness is not the guarantee of its sale. As GPV has been already explored, it has a positive effect on marketing performance (Sweeney et al. 1999). The GPV is much significant today, different companies can develop GPIN by emphasizing their product value (Steenkamp and Geyskens, 2006).

A Customer's concern in a product because of advantage of the product and its differences from competitors' products (Zeithaml, 1988; Aaker, 1996). Green product provides the same profit and performance as a non-green product and environment friendly, which increase values in the mind of customers to enhance its sale. GPV could not only play an important role in affecting GPIN but it also has a necessary determinant in maintaining long term customer relationship (Zhuang et al. 2010; Zeithaml, 1988). A few firms loose the attention of their customer by over stating the environmental value of their products (Kalafatis and Pollard, 1999). Past research posits that there is a positive relationship between GPV and GPT. These factors can increase post purchase customer's assurance for the product (Sweeney et al. 1999; Eid, 2011; Sirdeshmukh et al. 2002). Thus, the present study theorizes that GPV of customers is positively linked with GPIN and GPT and proposes the following hypotheses:

H4: There is a positive relationship between green perceived value and green purchase intention.

\section{Green Brand Image}

Green brand image is defined in this study as a set of perceptions and relations in the mind of the consumer that are connected to its environmental commitments and concerns (Cretu and Brodie, 2007; Padgett and Allen, 1997; Chen, 2009). The green brand image is assumed to have a positive effect on the Green purchase intention.

H5: There is a positive relationship between green brand image and green purchase intention.

\section{Green Awareness}

Awareness means to have the information about something. Green awareness (GAN) means to have the familiarity about the effects of a product on environment. When the people evaluate a product and its features and benefits in the context of environment, it is called 
GAN. A person, who will have more information about product and its performance, will be more aim to purchase it. It is in the case of green purchase intention. It proved that people, who have more education, are relatively more worried about the environment (Granzin and Olsen, 1991). GAN is most important part in green purchase intention (Maha and Ahmad, 2012). In 1993, Keller presented his conceptual model. In this conceptual model, he proved that the customer's reaction to marketing activities is interrelated with customer's brand knowledge and brand awareness.

An average consumer that has low knowledge and awareness of a green product will be less intends to purchase it. It also proved by (Rand Corporation. 2004) that there is a less opportunity for an average consumer to form an attitude about an environment friendly product than about a universal product, unless the customer tries to know about this product. As the companies, which are, manufacturing green products do not make clear green claims in their promotion campaign. Alston and Prince Roberts, (1990) originate that people desire to be more conscious about how the green products are, and what the clear advantages are. It is extremely stressed that consumers are less communicated about green products and the consumer will induced to buy green products if there is a better market communication of green products. It is also proved in many others researches that previous knowledge and awareness about a green product generate intention of customer to purchase green.

\section{H6: There is a positive relationship between green awareness and green purchase intention.}

\section{Environmental Advertisement}

In parallel with improving green movements worldwide and with rising public interest to environmental problems, most organizations have selected environmental advertisements through media or newspapers as green techniques for introducing their products to environmentally responsible consumers. The purpose of green advertisements is to influence consumers' purchase intention by inspiring them to buy products that do not hurt the environment and to direct their attention to the positive results of their purchase behavior, for themselves as well as the environment. Davis (1994) describes that environmental advertising by corporations usually contains three elements. Firstly, the advertisement starts with a statement of corporate concern for the environment. Secondly, the advertisement describes the method the corporation has changed its way in order to demonstrate its concern and dedication into civilizing the environment. Thirdly, the advertisement describes specific environmental actions in which the corporation is concerned and/or results for which the corporation takes credit. The reasons are:

The blurred arguments to substantiate the environmental claim, the basis country of the advertised product do not bear an eco-friendly image, the producer (advertiser) of the advertised product does not tolerate an eco-friendly image and the alleged eco-friendliness of the advertised product does not match with the respondent's preceding consumption experience. Green advertisement also creates awareness about green products. Media is a 
strong instrument for creating awareness. The purchase of green products is high in those areas where advertisement of green product is strong. So we can wind up that there is positive relation exists between advertisement and awareness.

\section{H7: There is a positive relationship between environmental advertisement and green purchase intention.}

\section{H8: There is a positive relationship between environmental advertisement and green awareness.}

\section{Research Methodology}

The current research is descriptive in its nature. Descriptive research can be defined as describe something some phenomena or any specific condition. Descriptive researches are those represents that represents the existing situation instead of translating and making decision. The key idea of the descriptive research is to verify the developed hypothesis that reflects the existing situation.

\section{Sample/Data}

In order to gather the data for understanding the condition about green marketing it was decided that the sample be formed by individuals over the age 18 -years-old. The reason is Individuals above this age are well-known with purchasing of products and are also empowered in their decisions for selecting the right items between many available choices. The way of data collection was a structured questionnaire. A total 150 individuals participated in the present study.

\section{Measures}

The survey instruments of current study address two major purposes: First is to analyze of different variables in the green marketing. Second, to collect information about the different characters of the respondents that can be used to understand the variation in different categories. The survey instrument contains two sections. Sections 1 include different personal and demographic variables. This section will obtain the respondents information about gender, age, education, status. Section 2 includes the latent variables that are important in the current study. This variable includes Green purchase intention, green perceived risk, green perceived trust, Green perceived value, Green brand image, Green awareness and environmental advertisement.

\begin{tabular}{|l|l|ll|}
\hline Sr \# & Variables & Items & \\
\hline 1 & $\begin{array}{l}\text { Purchase } \\
\text { Intention }\end{array}$ & i) & I would intend to buy green products \\
& & ii) & My willingness to buy green products is high \\
\hline
\end{tabular}




\begin{tabular}{|c|c|c|c|}
\hline & & $\begin{array}{l}\text { iii) } \\
\text { iv) }\end{array}$ & $\begin{array}{l}\text { I am likely to purchase any green product } \\
\text { I have a high intention to buy green product }\end{array}$ \\
\hline 2 & $\begin{array}{l}\text { Green } \\
\text { perceived } \\
\text { risk }\end{array}$ & $\begin{array}{l}\text { iii) } \\
\text { iv) } \\
\text { v) }\end{array}$ & $\begin{array}{l}\text { There is a chance that there will be something wrong with } \\
\text { environmental performance of this product. } \\
\text { There is a chance that this product will not work properly with } \\
\text { respect to its environmental design. } \\
\text { There is a chance that you would get environmental penalty or } \\
\text { loss if you use this product. } \\
\text { There is a chance that using this product will negatively affect } \\
\text { the environment. } \\
\text { Using this product would damage your green reputation or } \\
\text { image. }\end{array}$ \\
\hline 3 & $\begin{array}{l}\text { Green } \\
\text { perceived } \\
\text { trust }\end{array}$ & $\begin{array}{l}\text { i) } \\
\text { ii) } \\
\text { iii) } \\
\text { iv) } \\
\text { v) }\end{array}$ & $\begin{array}{l}\text { You feel that this product's environmental reputation is } \\
\text { generally reliable. } \\
\text { You feel that this product's environmental performance is } \\
\text { generally dependable. } \\
\text { You feel that this product's environmental claims are generally } \\
\text { trustworthy. } \\
\text { This product's environmental concern meets your expectations. } \\
\text { This product keeps promises and commitments for } \\
\text { environmental protection }\end{array}$ \\
\hline 4 & $\begin{array}{l}\text { Green } \\
\text { perceived } \\
\text { Value }\end{array}$ & $\begin{array}{l}\text { ii) } \\
\text { iii) } \\
\text { iv) } \\
\text { v) }\end{array}$ & $\begin{array}{l}\text { This product's environmental functions provide very good } \\
\text { value for you. } \\
\text { This product's environmental performance meets your } \\
\text { expectations. } \\
\text { You purchase this product because it has more environmental } \\
\text { concern than other products. } \\
\text { You purchase this product because it is environmental friendly. } \\
\text { You purchase this product because it has more environmental } \\
\text { benefit than other products. }\end{array}$ \\
\hline
\end{tabular}




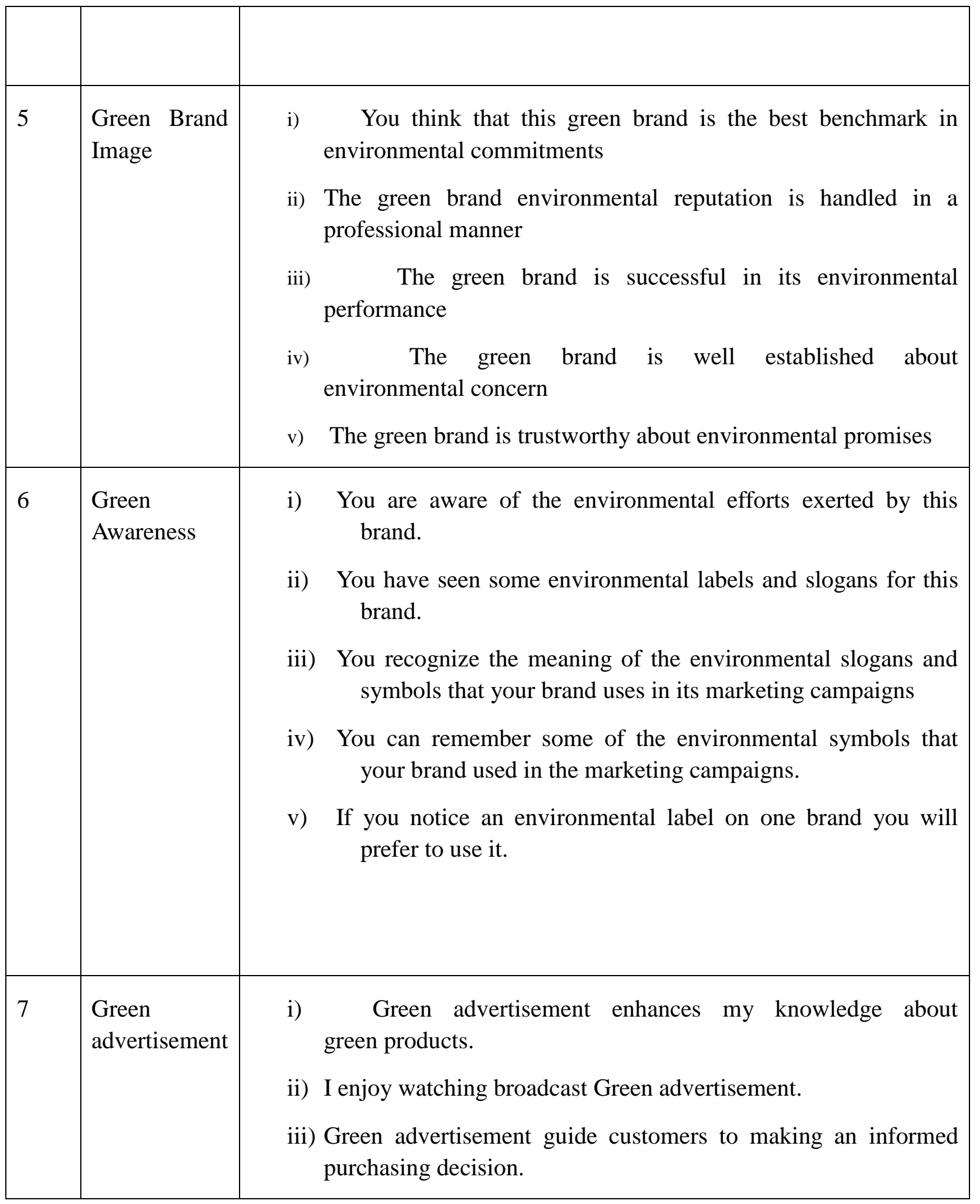

\section{Procedure}

The questioner was distributed among 160 respondents in Bahawalpur. These respondents are selected based on criteria above mentioned. Before giving the questioner the object of the 
study and questions were explain to the respondents so they can easily fill the questioner with related response. A total of 150 questioners were chosen and rest of the questioners was not included in the more analysis due to in complete or invalid responses after collecting the completed questioners, the questioners were coded and entered in SPSS sheet for further analysis.

\section{Reliability Analysis}

Cron Bach Alpha of all variables is more than expectable and recommended value 0.50 by Nunnally (1970) this shows that all the 32 items were reliable and valid to measure the opinions of consumers toward Green Marketing.

\section{Reliability of measure instruments}

\begin{tabular}{|l|l|l|}
\hline Scales & Items & Cron bach alpha \\
\hline Green Purchase Intention & 4 & 0.701 \\
Green perceived risk & 5 & 0.734 \\
Green perceived trust & 5 & 0.608 \\
Green perceived value & 5 & 0.612 \\
Green brand image & 5 & 0.701 \\
Green awareness & 5 & 0.631 \\
Green advertisement & 3 & 0.725 \\
& & \\
\hline
\end{tabular}

\section{Profile of Respondents}

Personal and demographic information such as gender, age, education, status are presented in the following table.

Profile of Respondents

\begin{tabular}{|l|l|l|l|}
\hline & Category & Frequency & Percentage \\
\hline Variable & & & \\
\hline Gender & Male & 62 & 41.3 \\
\hline
\end{tabular}




\begin{tabular}{|l|l|l|l|}
\hline & Female & 88 & 58.7 \\
\hline Age & $15-20$ years & 36 & 24 \\
$20-25$ years & 75 & 39 & 50 \\
25 years above & Bachelor & 106 & 26 \\
\hline Education & $\begin{array}{l}\text { Master } \\
\text { P.H.D }\end{array}$ & 2 & 70.7 \\
Status & Student & 104 & 28 \\
& Employed & 41 & 1.3 \\
\hline Businessman & 4 & 69.3 \\
& Unemployed & 1 & 27.3 \\
\hline
\end{tabular}

\section{Hypothesis Testing}

\section{Green perceived risk and Green Purchase intention}

According to the results of the study, the variable of the green perceived risk has a negative relationship with green purchase intention with $(B e t a=-0.148)$ and $(p<.05)$. That means Green Perceived Risk contributes $14.8 \%$ to Green Purchase Intention. Result of current study validates $H 1$.

\section{Green perceived risk and green perceived trust}

According to the results of the study, the variable of the Green perceived risk has a negative relationship with green perceived trust with(Beta=-.302) and $(\mathrm{p}<.05)$. That means Green perceived risk contributes $30 \%$ to green perceived trust. Result of current study validates $\mathrm{H} 2$.

\section{Green perceived trust and Green Purchase intention}

According to the consequences of the study, the variable of the Green perceived trust has a significant positive relationship with green purchased intention with (Beta=.186) and $(\mathrm{p}<.05)$. That means green perceived trust contributes $18 \%$ to green purchase intention. Result of current study validates $\mathrm{H} 3$.

\section{Green perceived value and Green purchase intention}

According to the results of the study, the variable of the Green perceived value and Green 
purchase intention are positively related with $($ Beta=.091) and $(\mathrm{p}<.05)$. That means Green perceived value contributes $9 \%$ to green purchase intention. . Result of current study validates $\mathrm{H} 4$.

\section{Green brand image and Green purchase intention}

According to the results of the study, the variable of the Green Brand image has positive effect on Green purchase intention with $($ Beta=.139) and $(\mathrm{p}<.05)$. That means Green Brand Image contributes $13 \%$ to green purchase intention. . Result of current study validates H5.

\section{Green Awareness and green purchase intention}

According to the results of the study, the variable of the Green Awareness has positive effect on Green purchase intention with $($ Beta $=.193)$ and $(\mathrm{p}<.05)$. That means Green Awareness contributes $19 \%$ to green purchase intention. . Result of current study validates H6.

\section{Green Advertisement and Green purchase intention}

According to the results of the study, the variable of the Green Advertisement has positive effect on Green purchase intention with $($ Beta=.348) and $(\mathrm{p}<.05)$. That means Green Advertisement contributes $34 \%$ to green purchase intention. . Result of current study validates $\mathrm{H} 7$.

\section{Green Advertisement and Green Awareness}

According to the results of the study, the variable of the Green Advertisement has positive effect on Green Awareness with (Beta=.594) and ( $\mathrm{p}<.05)$. That means Green Advertisement contributes $59 \%$ to green Awareness. Result of current study validates H8.

\section{Regression Results}

\begin{tabular}{|c|c|c|c|c|c|c|}
\hline Hypothesis & Model Variables & Estimate & S.E & C.R & $\mathbf{P}$ & Results \\
\hline $\mathrm{H} 1$ & GPR &.-148 & .066 & -2.592 & $<.05$ & Supported \\
\hline $\mathrm{H} 2$ & GPT & -.302 & .064 & -3.860 & $<.05$ & Supported \\
\hline H3 & GPI & .186 & .103 & 2.794 & $<.05$ & Supported \\
\hline $\mathrm{H} 4$ & GPI & .091 & .145 & 1.821 & $<.05$ & Supported \\
\hline H5 & GPIGBI & .139 & .127 & 2.269 & $<.05$ & Supported \\
\hline
\end{tabular}




\begin{tabular}{|l|ll|l|l|l|l|l|}
\hline H6 & GPIGA & $\longleftarrow$ & .193 & .117 & 1.600 & $<.05$ & Supported \\
\hline H7 & GPI & GAD & .348 & .091 & 2.841 & $<.05$ & Supported \\
H8 & GA & GAD & .594 & .051 & 8.899 & $<.05$ & Supported \\
\hline
\end{tabular}

\section{Discussion and implications}

The main objective of the study was to explore the relationship between consumer's purchase intention and green marketing. With the changes resulting from factor analysis, a modified research model emerged and one more dimension was added to green marketing tools that was named Green trust. An investigation on the coefficients of each dimensions of green marketing tool shows green perceived value, Green brand image, trust and advertisement and awareness as the positively significant variable related to Green purchase intention. it seems eco-branded products have been commercially successful due to its positive public image, which lead consumers to purchase and causing the growth to brand loyalty (Ginsberg and Bloom, 2004). It appear that awareness of eco-brand among consumers and their attention to buy environmentally branded products were influenced by their belief in the benefits of green products and protect the environment by purchase of eco-branded products. Environmental advertisement is a dimension of green marketing tool that is significant with green purchase intention. A majority of the respondents believed environmental advertisement enhances their knowledge on green products and they also consider green advertisement guides consumers into making an informed purchasing decision.

One of the factors contributing to the failure of applying environmental advertisements to enhance purchase behavior is due to low credibility of green advertisements among consumers (Kilbourne, 1995). According to Davis (1993), the factor resulting to consumer's weak response to environmental advertising is not the consequence of consumer's unwillingness to take action and change their behavior to purchase green products; rather consumers are unwilling to change their purchase behavior given the manner in which "green" products have been promoted and advertised. One of its specific reasons is the lack of specificity in many environmental claims that may have resulted in consumers forming a negative view of the green advertisement and advertised products. Therefore, this condition would unlikely lead to the purchase of environmental friendly products. Consumers believe that the environmental advertisements increase their knowledge about green products. Mass media, television and newspapers are two majors media to acquire information by people (Mat Said et al., 2003) however, due to the lack of environmental advertisements, people are not familiar with most of the alternative products. In this study, the relationship between Green trust, Green brand image, green perceived value and Green purchase intention are 
found to be significant. This means that the respondent's trust Green brand image, green perceived value has a positive effect on consumer's purchase intention. Without consumer's confidence and trust, it is very difficult to convince them to make purchase decisions.

\section{References}

1 Chen, Y.-S. (2011), “Green organizational identity: sources and consequence”,Management Decision, Vol. 49 No. 3, pp. 384-404

2 Chen, Y.-S. (2010), "The drivers of green brand equity: green brand image, green satisfaction, and green trust",Journal of Business Ethics, Vol. 93 No. 2, pp. 307-19.

3 Peattie, K. (1995),Environmental Marketing Management, Pitman Publishing, London. Peter, J.P. and Ryan, M.J. (1976), "An investigation of perceived risk at the brand level”,Journal of Marketing Research, Vol. 13 No. 2, pp. 184-9

4 Porter, M.E. and van der Linde, C. (1995), "Green and competitive",Harvard Business Review,

Vol. 73 No. 5, pp. 120-34. 5 Peter, J.P. and Ryan, M.J. (1976), “An investigation of perceived risk at the brand level”,Journal of Marketing Research, Vol. 13 No. 2, pp. 184-9.

6 Mitchell, V.W. (1999), “Consumer perceived risk: conceptualizations and models”,European Journal of Marketing, Vol. 33 No. 1, pp. 163-95

7 Gregg, D.G. and Walczak, S. (2008), "Dressing your online auction business for success: and experiment comparing two e-Bay businesses", MIS Quarterly, Vol. 32 No. 3, pp. 653-70.

8 Chang, H.H. and Chen, S.W. (2008), "The impact of online store environment cues on purchase intention: trust and perceived risk as a mediator",Online Information Review, Vol. 32 No. 6, pp. 818-41.

9 Chaudhuri, A. (1997), "Consumption emotion and perceived risk: a macro-analytic approach”, Journal of Business Research, Vol. 39 No. 1, pp. 81-92

10 Wood, C.M. and Scheer, L.K. (1996), "Incorporating perceived risk into models of consumer deal assessment and purchase intent", in Corfman, K.P. and Lynch, J.G. Jr (Eds),Advances in Consumer Research, Vol. 23, Aassociation for Consumer Research, Provo, UT, pp. 399-406.

11 Rotter, J.B. (1971), “Generalized expectancies for interpersonal trust”,American Psychologist, Vol. 26 No. 5, pp. 443-50.

12 Hart, P. and Saunders, C. (1997), "Power and trust: critical factors in the adoption and use of electronic data interchange",Organizational Science, Vol. 8 No. 1, pp. 23-42

13 Strong, C. (1996), "Features contributing to the growth of ethical consumerism: a preliminary investigation", Marketing Intelligence \& Planning, Vol. 14 No. 5, pp. 5-13. 


\section{Macrothink}

Journal of Sociological Research

ISSN 1948-5468

2014, Vol. 5, No. 1

14 Tai, S.H.C. and Tam, J.L.M. (1997), "A lifestyle analysis of female consumers in Greater China”, Psychology \& Marketing, Vol. 14 No. 3, pp. 287-307.

15 Pickett, G.M., Kangun, N. and Grove, S.J. (1995), “An examination of the conserving consumer: implications for public policy formation in promoting conservation behaviour", in Polonsky, M.J. and Mintu-Wimsatt, A.T. (Eds),Environmental Marketing: Strategies, Practice, Theory, and Research, The Haworth Press, New York, NY, pp. 77-99.

Rizwan, M., Khan, A, A., Misbah, K. A., Nawaz, I., Tahir, S., Siddique, A. and Gillani, S. N. A. (2013). Measuring the Scope of Green Products in Developing Countries: A Myth Breaking Study, American Journal of Scientific Research, 85, 32-46

16 Schultz, W. and Zelezny, L. (1999), "Values as predictors of environmental attitudes: evidence for consistency across 14 countries", Journal of Environmental Psychology, Vol. 19 No. 3, pp. 255-65.

17 Mintel (2006), “Green living”, US Marketing Research Report, London. Morris, L., Hastak, M. and Mazis, M. (1995), "Consumer comprehension of environmental advertising and labeling claims", The Journal of Consumer Affairs, Vol. 29 No. 2, pp. 328-51.

18 Rex, E. and Baumann, H. (2007), "Beyond ecolabels: what green marketing can learn from conventional marketing",Journal of Cleaner Production, Vol. 15 No. 6, pp. 567-76

19 Rizwan, M., Ahmad, S. U. \& Mehboob, N. (2013) Enhancing the Green Purchase Intention Based on Green Marketing: An Empirical Study from Pakistan, Asian Journal of Empirical Research, 3(2), 208-219 